\title{
SPOŁECZNE FUNKCJE I EDUKACYJNE ZNACZENIE UCZESTNICTWA KOBIET W CIĄŻY ORAZ MAŁYCH DZIECI W KONCERTACH MUZYKI KLASYCZNEJ
}

\section{Wprowadzenie}

Celem artykułu jest zaprezentowanie wyników badań, które skupione były wokół poznania społecznych funkcji, a także edukacyjnego, stratyfikacyjnego oraz symbolicznego znaczenia uczestnictwa w koncertach muzyki klasycznej dla kobiet w ciąży oraz niemowląt i małych dzieci na przykładzie cyklu organizowanych przez Filharmonię Pomorską w Bydgoszczy koncertów, zatytułowanych „Od brzuszka do uszka maluszka”. Problemy badawcze, jakie postawiłam są następujące:

1. Jakie funkcje pełnią koncerty dla kobiet w ciąży oraz małych dzieci do lat 2?

2. Jaka jest koncepcja koncertów?

3. Jaki jest przebieg koncertów?

4. Jakie znaczenie dla rozwoju płodu i małych dzieci ma słuchanie muzyki?

Badanie koncertów odbyło się metodą obserwacji uczestniczącej [Mayntz, Holm, Hübner 1985; Angrosino 2010; Babbie 2005] w okresie od października 2015 roku do lutego 2017 roku i zostały oparte na schemacie obserwacji zawierającym kategorie wywodzące się z problemów badawczych. Dokonałam także analizy dokumentów zastanych (głównie materiałów informacyjnych przygotowanych i przekazanych przez Filharmonię Pomorską). Obserwacje uzupełnione zostały sześcioma wywiadami swobodnymi z aktualnie przygotowującą koncerty dr Katarzyną Szewczyk. Poza wywiadami, przeprowadziłam merytoryczne konsultacje z ekspertami, czyli osobami przygotowującymi koncerty: dr Katarzyną Szewczyk i dr Anną Nogaj (miały one charakter dyskusji eksperckich w formie rozmów telefonicznych i wymiany korespondencji, i służyły doprecyzowaniu 
szczegółowych kwestii związanych z teoretycznymi i metodycznymi założeniami programowymi koncertów, a także dostarczeniu wiedzy z zakresu pedagogiki muzyki oraz psychologii muzyki na temat wpływu muzyki na rozwój dzieci). Ponadto, pracownicy Filharmonii Pomorskiej przekazali mi dokumenty związane $\mathrm{z}$ organizacją koncertów (założenia programowe, metodyczne, edukacyjne).

Poza funkcją edukacyjną (jawną), badane koncerty pełnią wiele innych ważnych społecznych funkcji i właśnie ich omówienie jest celem tego artykułu. Ważne dla mnie, jako socjologa, będzie także ukazanie związków między słuchaniem muzyki klasycznej oraz uczestnictwem w kulturze wysokiej z funkcjami rodziny, a także wskazanie na psychologiczne uwarunkowania odbioru muzyki klasycznej przez dzieci w okresie prenatalnym oraz przez małe dzieci.

Uzasadnieniem przeprowadzenia badań była potrzeba podjęcia próby wykazania związku między udowodnionym pozytywnym wpływem słuchania muzyki na rozwój małego dziecka już od okresu prenatalnego a wczesnym różnicowaniem się szans edukacyjnych dzieci, budowaniem kapitału kulturowego, społecznego oraz stratyfikacją społeczną.

Badacze dowodzą, że:

muzyka stanowi dziedzinę szczególnie sprzyjającą spontanicznej, aktywnej, twórczej wypowiedzi dziecka, chociażby ze względu na różnorodność środków wyrazu: słowo, śpiew, ruch, dźwięki instrumentów, różne efekty akustyczne, skojarzenia plastyczne itp. Chodzi zarówno o wydobywanie, uzewnętrznienie muzyki, którą „dziecko nosi w sobie”, jak i reagowanie na muzykę odbieraną z zewnątrz. Z punktu widzenia estetyki, muzyka kształtuje wrażliwość na piękno, rozwija wyobraźnię, uczy samodzielności i oceny estetycznej [Kisiel 2007: 15].

I nie tylko. Dowiedziono na przykład, że edukacja muzyczna niemowląt kształtuje integrację społeczną [Zwolińska 2016: 55, 119]. Ewa Zwolińska podaje, że dzieci już w okresie płodowym oraz niemowlęta cechuje wrażliwość muzyczna [Zwolińska 2016: 73]. To właśnie na bazie wiedzy filozoficznej, estetycznej, psychologicznej, socjologicznej [Sacher 2015: 17-66] rozwinęła się pedagogika muzyki, której przedmiotem są „wszelkie procesy związane z nauczaniem i uczeniem się muzyki oraz ich szeroki kontekst społeczny i kulturowy" [Sacher 2015: 74]. Badane koncerty służą realizacji misji powszechnego kształcenia i wychowania przez muzykę, realizowanego nie tylko w szkole [Krzemińska 2012]. Według Wiesławy Sacher [termin ten oznacza: 
wszelką działalność dydaktyczną, zamierzoną i niezamierzoną, instytucjonalną i nieformalną włącznie z procesami samokształcenia, skierowaną na korzystne zmiany w poziomie wiedzy i umiejętności muzycznych oraz w osobowości, postawach i przyjmowanych systemach wartości wynikających z kontaktów z tą dziedziną sztuki [Sacher 2015: 69].

Jak pisze Barbara Jabłońska w Socjologii muzyki, muzyka jest jednym z powszechników kulturowych: „w zasadzie nie znamy kultur, które nie miałyby swojego życia muzycznego" [Jabłońska 2014: 18].

$\mathrm{W}$ niniejszym artykule wskazana zostanie jedna $\mathrm{z}$ dróg, jaką wybierają rodzice, którzy przez uczestniczenie w kulturze wysokiej i słuchanie muzyki klasycznej z dziećmi w sposób rytualny, symboliczny - jak postaram się udowodnić - wprowadzają je w świat klasy średniej i wysokiej. Maksymalizują w ten sposób ich edukacyjne szanse życiowe [Meighan 1993: 321-387, Sztompka 2004: 337], wykorzystując stymulujący wpływ muzyki na rozwój mózgu oraz wyposażając w specyficzne, ważne z punktu widzenia systemu szkolnego, kompetencje. Do odbioru muzyki

ważne są bowiem kulturowo-społeczne ramy nadające sens powiązanym ze sobą dźwiękom, które stają się dla słuchaczy muzyką. Co więcej, ludzie muszą się też nauczyć, w jaki sposób zachowywać się podczas różnorodnych sytuacji związanych z muzyką (jej tworzeniem, słuchaniem, wspólnym muzykowanie, dzieleniem się nią itp.). Ponadto muzyka wiąże się z pewnymi ustalonymi i zinstytucjonalizowanymi rytuałami i zachowaniami ceremonialnymi, które pozwalają odnaleźć się jednostkom w danym kontekście słuchania [Jabłońska 2014: 27].

Oznacza to, że branie udziału w koncertach - swoistych rytuałach interakcyjnych, uczenie się rytualnych porządków [Goffman 2006: 43-46] oraz reguł zaangażowania, konwenansów i rytualnej organizacji zachowań w rozumieniu, jakie im nadał Erving Goffman [2008], jest powiązane $\mathrm{z}$ wprowadzaniem nowego pokolenia w środowisko kultury wysokiej i stanowi element socjalizacji w pewnym kręgu społecznym [Filipiak 2003: 89-100]. Procesy te wiążą się z internalizacją symboli [Collins 2011] oraz społecznym tworzeniem i konstruowaniem emocji [Turner, Stets 2009], które wywołuje muzyka [Mrozowicz-Wrońska, Cipora, Czernecka 2015: 83-97], o czym szeroko pisze Malcolm Budd w dziele Muzyka i emocje [2014].

Jak zauważa Piotr Sztompka sformalizowane i standaryzowane praktyki mają szczególne znaczenie dla „przenoszenia się” w czasie wzorów normatywnych (...). Rytuały związane $\mathrm{z}$ życiem muzycznym warunkowane są oczywiście danym kręgiem kulturowym, czasem historycznym i epoką, jak również właściwościami struktury społecznej [Jabłońska 2014: 27]. 
Organizatorzy koncertów - co ustaliłam podczas prowadzonych badań - nie ukrywają, że wychowują sobie przyszłą publiczność, czyli ludzi, dla których uczestnictwo w koncercie muzyki klasycznej będzie potrzebą, elementem stylu życia, dystynkcją, sposobem na podtrzymanie tożsamości społecznej, manifestacją gustu [Bourdieu 2005] oraz umiejętności odpowiedniego słuchania w rozumieniu Stockfelta [Jabłońska 2014: 29]. Chodzenie do filharmonii ma się stać dla nich normatywną regułą [por. Sacher 2015: 245-249], wszak:

aby muzyka stała się dla ludzi znacząca oraz by możliwe było jej tworzenie, odbiór, interpretacja, wspólne bądź indywidualne przeżywanie itp., potrzebny jest cały proces przygotowujący jednostki do recepcji muzyki, jak również do identyfikacji odpowiednich kontekstów słuchania, stylów czy gatunków muzycznych. Chodzi tu nie tylko o internalizację odpowiednich reguł związanych z życiem muzycznym, lecz o wyrobienie odpowiednich kompetencji estetycznych, wrażliwości na dźwięki, gustów bądź umiejętności poruszania się w muzycznych kontekstach, które mają społeczny charakter [Jabłońska 2014: 27-28].

Już na początku artykułu należy podkreślić, że Pierre Bourdieu zauważył, że wpływ na kontekst odbioru ma zajmowana przez jednostkę pozycja społeczna: „estetyczne słuchanie powiązane jest $\mathrm{z}$ odpowiednim smakiem muzycznym, determinowanym posiadanymi kompetencjami i dyspozycjami estetycznymi” [Jabłońska 2014: 29].

\section{Charakterystyka cyklu koncertów „Od brzuszka do uszka maluszka” i jego społeczne funkcje w świetle badań własnych}

Omawiane koncerty odbywają się od 25 maja 2008 roku, a 10 marca 2018 roku miało miejsce dziewięćdziesiąte siódme spotkanie z tego cyklu. Pomysłodawczyniami, autorkami koncepcji oraz pierwszymi prowadzącymi i konsultantkami tych koncertów są: była dyrektor Filharmonii Pomorskiej Eleonora Harendarska, dr hab. Barbara Kamińska, kierownik Międzywydziałowej Katedry Psychologii Muzyki Uniwersytetu Muzycznego Fryderyka Chopina, oraz Adriana Kordas, ówczesna edukatorka muzyczna Filharmonii Pomorskiej. Od października 2011 roku koncerty prowadziły dr Anna Nogaj (Gluska), psycholog muzyki, i skrzypaczka, Dorota Borowicz, magister sztuki - specjalność wokalistyka, a od października 2012 roku stałą prowadzącą oraz przygotowującą koncerty jest dr Katarzyna Szewczyk, dyrygentka chóralna, specjalistka edukacji muzycznej oraz logopeda. 
Koncerty „Od brzuszka do uszka maluszka” są organizowane w Filharmonii Pomorskiej w Bydgoszczy, czyli w instytucji związanej z wykonawstwem muzycznym, a szczególnie z koncertowaniem na żywo [Jabłońska, 2014: 47], a także z edukacją muzyczną, upowszechnianiem muzyki, szczególnie wśród dzieci (audycje szkolne, audycje muzyczne on-line, koncerty i konkursy dla młodzieży). Filharmonia Pomorska organizuje trzy rodzaje koncertów dla dzieci - opisywany: „Od brzuszka do uszka maluszka”, a także „Akademię Wiolimisia” oraz „Muzyczne Bajkoranki”. Wszystkie koncerty dla dzieci rozpoczynają się piosenką skomponowaną przez Marcina Gumielę, do której słowa napisały wspólnie Prelegentki Filharmonii Pomorskiej:

Dziś się spotykamy, / Aby w muzyki świat zaprosić was / Wspólnie zaśpiewamy / Instrumenty swą moc pokażą dziś wam

Rytm, dźwięk oto muzyki świat / Dla was filharmonia dziś gra / Piano forte - forte piano / Zaczynamy koncertu już czas

Charakter dobranych podczas koncertów utworów odpowiada założeniom Modelu Mobilnej Rekreacji Muzycznej Macieja Kieryło, wykorzystywanemu między innymi w muzykoterapii. Etapy tego modelu to: uruchomienie, odreagowanie, zrytmizowanie, uwrażliwienie, relaksowanie, aktywizacja. Do każdego z etapów dobrane są ilustracyjne utwory muzyczne, pasujące tempem i nastrojem, oraz zadania aktywizujące i edukacyjne, korespondujące $\mathrm{z}$ tematem przewodnim koncertu. Założenia programowe opracowane przez dr hab. Barbarę Kamińską są następujące:

1. Muzyka dla najmłodszych musi być wartościowa pod względem artystycznym, szczególnie starannie dobrana pod względem nastroju i aparatu wykonawczego.

2. Muzyka wymaga skupienia, skoncentrowania się na świecie dźwięków - ich barw, współbrzmień, przebiegu melodii, nastroju. Dlatego nasze koncerty są raczej spotkaniami z muzyką niż zabawami przy muzyce. Dzieci reagują na muzykę spontanicznie. Jedne są zasłuchane, inne pobudzone do ruchu.

3. Wspólne doświadczanie muzyki - małego dziecka z osobą dorosłą - jest okazją do dzielenia przeżyć i emocji muzycznych, najlepiej w ramionach osoby bliskiej, w atmosferze miłości rodzicielskiej. Powinno być swoistym rytuałem, świętem, chwilą kojarzącą się z poczuciem bezpieczeństwa i radości.

4. Dla małych dzieci szczególnie fascynujący jest śpiew innych dzieci oraz osób najbliższych. Na każdym koncercie uczymy rodziców piosenek przekazywanych z pokolenia na pokolenie, zachęcamy do śpiewania ich w domu i przypominamy, że śpiew jest najważniejszy dla rozwoju małych dzieci [Kamińska 2010: 3]. 
Jak wcześniej wspomniałam, koncerty „Od brzuszka do uszka maluszka" odbywają się od dziesięciu lat. Bilety na koncert kosztują 20 złotych dla osoby dorosłej i osiem złotych dla dziecka, organizowane są w soboty, raz $\mathrm{w}$ miesiącu. Ich tematyka jest związana $\mathrm{z}$ porą roku (np. powiązane z tradycjami świątecznymi, dźwiękami przyrody lub skoncentrowane wokół konkretnego instrumentu muzycznego). W minionym sezonie artystycznym realizowany był cykl „muzycznych podróży” do różnych krajów europejskich (Austrii, Irlandii, Włoch, Francji, Hiszpanii). Repertuar powiązano z konkretnymi kompozytorami pochodzącymi z tych miejsc, a także z pochodzeniem muzyków wykonujących poszczególne utwory. Przykładowo, „Muzyczna podróż do Chin” to koncert, podczas którego występowali studenci pochodzący z Chin, studiujący na bydgoskiej Akademii Muzycznej w klasie fortepianu oraz na Wydziale Wokalno-Aktorskim. Oczywiście wykonywali oni także utwory napisane przez chińskich kompozytorów, a także uczyli rodziców liczyć w języku chińskim. Podczas koncertu „Muzyczna podróż do Rosji” wykonywane były utwory kompozytorów rosyjskich, a także były zaprezentowane tańce $\mathrm{z}$ klasycznego repertuaru baletu rosyjskiego przez tancerkę z zespołu baletowego Opery Nova w Bydgoszczy. Atrakcją koncertu „Muzyczna podróż do Hiszpanii” był występ tancerki wykonującej tradycyjne tańce hiszpańskie (m.in. flamenco). Muzycy podczas koncertów grają na instrumentach pochodzących $\mathrm{z}$ wybranych krajów ${ }^{1}$. Można zatem stwierdzić, że omawiany cykl koncertów pełni funkcję kulturoznawczą, a także stanowi element wczesnej edukacji międzykulturowej, czyli wzbudzania szacunku do innych kultur, otwartość, zainteresowanie muzyką komponowaną i wykonywaną w innych regionach świata, a także znacznie poszerza wyobraźnię dźwiękową [por. Frołowicz 2015: 84]. Warto podkreślić, że badane koncerty pełnią także funkcję wprowadzenia w świat wartości [Sacher 2006] oraz transmisji kulturowej przez przekazywanie dzieciom zdobyczy kultury i wprowadzanie ich w symboliczną kulturę muzyki [Suświłło 2006: 126-127].

Niewątpliwie muzyka pełni różne funkcje, między innymi estetyczną, komunikacyjną, integracyjną, tożsamościową, ekspresyjną, rozrywkową (ludyczną), użytkową, terapeutyczną, mobilizacyjną, polityczną (ideologiczną), religijną, ekonomiczną [Jabłońska 2014: 31-43]. Omawiane koncerty pełnią, jak sądzę, głównie funkcję edukacyjną, wychowawczą i rozrywkową. Funkcja wychowawcza koncertów polega na realizowaniu w praktyce

$1 \quad$ Na przykład cajon - kahon, skrzynia hiszpańska. 
przekonania, że: „aby ludzie mogli przeżywać muzykę i doświadczać przyjemności obcowania z nią, muszą się nauczyć, w jaki sposób ją odbierać (...); oznacza to, że muzyka jest możliwa jedynie tam, gdzie społeczeństwa socjalizują swoich członków do odpowiednich "sposobów słuchania»" [Jabłońska 2014: 35]. W trakcie socjalizacji pierwotnej i wtórnej zachodzi proces uczenia się odbioru muzyki, specyfiki muzycznych gatunków, umiejętności oceny wartości estetycznej utworów muzycznych, reguł słuchania, sposobów zachowania się w muzycznych kontekstach, odgrywania społecznych ról (słuchacza, twórcy, odtwórcy dzieła). Za pomocą funkcji wychowawczej muzyki możliwe jest kształtowanie wnętrza człowieka przez wyrobienie smaku estetycznego, wrażliwości na piękno, wprowadzanie w kulturę muzyczną i symboliczną, podnoszenie jakości życia oraz rozwijanie innych kompetencji i umiejętności: „za pomocą muzyki (i sztuki w szerszym rozumieniu) realizowane jest szeroko pojęte zadanie uspołecznienia jednostek i uczynienia ich dobrymi członkami społeczeństwa" [Jabłońska 2014: 36], a także doskonalenie gustu [Górniok-Naglik 2000: 63-64] oraz stwarzanie warunków uczestnictwa w muzycznym dyskursie [Białkowski 2006: 85]. Wedle Mirosławy Zalewskiej-Pawlak, to sztuka stanowi zasadniczy element humanistycznej orientacji wychowawczej, a potrzeba wychowania przez sztukę $\mathrm{i}$,do sztuki jest wpisana w polską tradycję edukacji estetycznej. Określenie sztuki jako dobra pośredniczącego kultury w pełni odpowiada tej trwałej tendencji w pedagogice" [Zalewska-Pawlak 2001: 181]. Wiedza, którą czerpać można ze sztuki jest źródłem mądrości i zrozumienia istoty człowieczeństwa [Zalewska-Pawlak 2001: 183].

Warto w tym miejscu podkreślić, że koncert, jako forma kontaktu z muzyką wykonywaną na żywo [Sacher 2015: 187-189], stanowi wedle pedagogów muzyki okazję do realizowania edukacji muzycznej, ponieważ potrzebne jest „systematyczne nauczanie i systematyczny udział w koncertach. Tak prezentowana muzyka oddziałuje bowiem najintensywniej" [Sacher 2015: 155] W Niemczech realizuje się tak zwaną pedagogikę koncertową. Edukacja koncertowa jest skuteczna ze względu na możliwość bezpośredniego, wielozmysłowego doświadczenia powstawania muzyki, niepowtarzalnego przeżycia estetycznego oraz emocjonalnego (np. wzruszenia) poznania wspólnoty słuchaczy. Wiesława Sacher podkreśla, że koncerty muzyki klasycznej skierowane do dzieci zawsze cechuje wysoki poziom wykonawczy, a także szczególna troska o dobór repertuaru, w celu rozwijania wrażliwości artystycznej i emocjonalnej [Sacher 2004: 210-221], zainteresowania dziełami sztuki muzycznej [Sacher 2015: 157]. Anna Pikała uważa, że kształcenie postaw kreatywnych oraz „nauczanie każdego dziecka 
estetycznego postrzegania i praktyki estetycznej jest jednym z głównych zadań dzisiejszej edukacji" [Pikała 2002: 39]. Ważne jest ponadto między innymi rozwijanie umiejętności świadomego odbioru muzyki, wyrabianie „umiejętności postrzegania, wartościowania piękna oraz jego przeżywania” [Pikała 2002: 158]. Koncerty edukacyjne oraz audycje stwarzają ku temu okazję - przyczyniają się do aktywnego słuchania, poszerzają horyzonty, dostarczają wiedzy muzycznej, są „ważnym krokiem na drodze do pokochania muzyki” [Górniok-Naglik 2000: 62].

Jednak, jak dalej pisze Barbara Jabłońska w Socjologii muzyki, można wyróżnić także dysfunkcje muzyki: dezintegracyjno-konfliktogenną, alienacyjno-ekskiapiczną, transyczno-narkotyczną, agresywno-destrukcyjną, perswazyjno-manipulacyjną, inwazyjno-patogenną oraz plądrofoniczno-kłusowniczą. Z punktu widzenia odpowiedzi na postawione pytania badawcze, warto zwrócić uwagę szczególnie na dysfunkcję dystynktywnosegregacyjną. Muzyka może sprzyjać klasowym podziałom w społeczeństwie „wyznaczając różnice pomiędzy jednostkami zajmującymi określone pozycje w strukturze społecznej i konsumującymi określone gatunki muzyczne. W ten sposób jednostki mogą podkreślać swoją przynależność do danej zbiorowości lub ją podkreślać" [Jabłońska 2014: 44]. Wydaje się, że omawiane koncerty, mimo, że cena biletu nie jest wysoka, mogą pełnić taką funkcję w zakresie wyboru sposobu spędzania wolnego czasu przez rodzinę. Udział w tego typu koncertach jest - jak sądzę - jednym $z$ elementów reprodukcji struktury społecznej przez rodzinę, świadomą pozytywnego wpływu uczestnictwa w kulturze wysokiej na rozwój poznawczy i emocjonalny ich dziecka. Z obserwacji wynika, że uczestnikami koncertów są osoby związane ze środowiskiem muzycznym, naukowym, biznesowym, a także pedagodzy (często spotykałam absolwentów pedagogiki UKW oraz nauczycieli akademickich). Oczywiście, aby poznać dokładny skład demograficzny należałoby przeprowadzić regularne badanie kwestionariuszowe (co - zważywszy na charakter koncertów mogłoby być trudne, jeśli nie niemożliwe).

Badania ogólnopolskie GUS dowodzą jednak, że, jak pisze Tomasz Szlendak:

w 2009 roku chodzenie do filharmonii deklarowało zaledwie 4 procent respondentów $(3,4 \text { procent wśród mężczyzn i } 4,5 \text { procent wśród kobiet })^{2}$ (...). Osoby najgorzej wykształcone ani do filharmonii, ani do sal koncertowych nie chodzą właściwie w ogóle (było tam 3,7 procent osób po szkole podstawowej i 6,5 procent po zasadniczej zawodowej). Jeśli ktoś do nich chodzi, to zdecydowanie są to respondenci wyżej wykształceni (32 procent), zostawiając daleko za sobą osoby z maturą 
(15,9 procent). Bez cienia wątpliwości muzyka w filharmoniach to rozrywka dla "getta obeznanych", rodzaj enklawy dla osób wykonujących inteligenckie zawody (do tej właśnie formy aktywności „przyznaje się” aż 40,4 procent spośród nich). Dla porównania, w kategoriach osób wykonujących zawody robotnicze i osób zatrudnionych $\mathrm{w}$ przemyśle do filharmonii poszło w ostatnim roku po 10 procent respondentów (co i tak jest arcyciekawym, bo wysokim na tle dotychczasowej wiedzy odsetkiem), natomiast pośród reprezentantów zawodów „usługowych” 18,7 procent. Zwolennicy koncertów w filharmoniach rekrutują się też raczej spośród respondentów najbogatszych (21,9 procent) niźli z najbiedniejszych (14,7 procent $)^{3}$, [Szlendak 2014: 158-159].

Oznacza to, że uczęszczanie do filharmonii wraz z dziećmi, poza wartością autoteliczną, jest sposobem na obronę oraz reprodukowanie w kolejnym pokoleniu inteligenckiego statusu społecznego, kształtowanie odpowiednich dla klasy średniej i wyższej nawyków, rytuałów oraz dystrybucji czasu wolnego [Domański 2004: 49-61, 83-89], a także legitymizowanie właściwych klasie praktyk kulturalnych. Jak pisał Ralf Linton, w społeczeństwach:

występują zazwyczaj oczekiwania, że jednostki o wysokim prestiżu powinny zachowywać się w określony sposób (...). Każdy system klasyfikacji i organizacji (...) przypisuje jednostkom na podstawie ich pozycji w systemie pewne wzory kulturowe. Najwyraźniej pozycja jednostki w systemie płci i wieku w znacznie większym stopniu niż jakakolwiek inna determinuje jej uczestnictwo w kulturze [Linton 1975: 89].

Nie bez znaczenia, wedle Lintona, jest także rola rodziny: „uczestnictwo kulturowe wspólne członkom takich grup dostarcza czegoś w rodzaju stałej ramy odniesienia" [Linton 1975: 90], oraz wpisuje się w realizowany przez rodzinę styl życia [Szlendak 2010: 209-213, 231, 245-252] oraz style wychowania. Uczestnictwo w kulturze

wynika z postaw, nawyków i umiejętności, czyli dyspozycji wewnętrznych - a te w odniesieniu do kultury nie są dziedziczone biologicznie ani przyjmowane automatycznie przez jednostkę (...). Różne okoliczności wychowawcze, różne sposoby, kierunki i stopnie kształcenia odgrywają tu wielką rolę. Także ogólne cechy kulturowe danej grupy (rodziny, narodu, warstwy społecznej) wytwarzają takie a nie inne inspiracje do uczestnictwa lub - przeciwnie - przeszkody [Golka 2007: 125].

W $2014-6,3 \%$, GUS [2016: 87].

Por. GUS [2016: 86-87]: „Na koncerty do filharmonii uczęszczało 6,0\% osób (o 2,0\% więcej niż w 2009 r.) - 5,5\% melomanów wśród mężczyzn i 6,4\% wśród kobiet. Spośród mieszkańców miast na koncerty muzyki poważnej uczęszczało 8,3\% osób, a spośród mieszkańców wsi - 2,4\% osób”. 
Pisał o tym zjawisku Pierre Bourdieu, ponieważ wedle jego teorii,

kultura jest więc wyczuciem wykwintnego sposobu życia, manier, wyrafinowania, lub dystyngowanej swobody w interakcjach społecznych, które stanowią sedno sposobu, w jaki jednostki demonstrują społeczne obycie (...). Społeczne walki o odróżnienie się mają także wymiar kulturowy: kultywowanie własnego „ja” jest również kwestią edukacji, estetyki i sztuki. Sformułowane przez Bourdieu pojęcie kapitału kulturowego kieruje naszą uwagę na to, w jaki sposób - za sprawą klasyfikującej siły smaku, znajdującej wyraz w konsumowaniu kultury - wytwarzane są nierówności społeczne [Elliott 2011: 176].

Na zjawisko to zwróciła także uwagę Wiesława Sacher w Pedagogice muzyki przywołując problem przemocy symbolicznej $\mathrm{w}$ odniesieniu zarówno do marketingu związanego z muzyka popularną, jak i edukacji muzycznej realizowanej w praktyce edukacyjnej [Sacher 2015: 63].

Uczestnictwo w koncertach dla dzieci jest formą uczestnictwa w kulturze, która wedle Mariana Golki niejako „stwarza człowieka”, jednocześnie będąc efektem procesu wychowania i kształcenia, będąc formą interakcji społecznej [Golka 2007: 123-125]. Opisywany typ uczestnictwa w kulturze wpływa na umiejętność widzenia świata społecznego, wyrabiając stosunek do społecznej rzeczywistości oraz pełni także funkcję budowania kapitału kulturowego, czyli wiedzy symbolicznej, a także wysokiego kapitału społecznego dziecka przez socjalizowanie według opisywanego przez Barbarę Fatygę wzorca człowieka kulturalnego [Fatyga 2014: 69] i nadawanie dziecku tej tożsamości i kształtowania osobowości statusowej [Linton 1975: 147]. Według Pierre’a Bourdieu, „klasa tworzy habitusy, habitusy tworzą klasę” [Mikiewicz 2016: 159]. Kapitał kulturowy, to jak wiadomo,

specyficzna kompetencja w posługiwaniu się symbolami kultury jako zasobem, który można wykorzystywać w grze (...). O tym, jakie kompetencje kulturowe są kapitałem, decyduje logika pola (...). Umiejętności kulturowe, zwłaszcza te o charakterze ucieleśnionym (długotrwałe dyspozycje ciała i umysłu, dobre maniery, gust kulturowy, smak, znajomość form kultury wysokiej, konwencji kulturowych i towarzyskich), są nierównomiernie dystrybuowane w społeczeństwie. Szczególnie istotne tu są umiejętności posługiwania się kodami tzw. kultury wysokiej (...). Kapitał kulturowy ucieleśniony najbardziej jest związany z socjalizacją i warunkami egzystencji. Stanowi efekt długotrwałego treningu, ćwiczenia, praktykowania. Jest ucieleśniony, czyli jest w nas, wdrukowany niejako w nasze sylwetki, ruchy postawy, gesty [Mikiewicz 2016: 161].

Uczestnictwo w koncertach dla kobiet w ciąży oraz dla najmłodszych dzieci oznacza zatem realizowanie przez rodzinę funkcji stratyfikacyjnej, 
socjalizacyjnej (czyli „przekształcanie niemowląt w ludzi” [Szlendak 2014] - poprzez przekazywanie kultury z pokolenia na pokolenie), a także funkcji identyfikacyjnej i emocjonalnej. Rodzina taka poprzez uczestnictwo w kulturze wysokiej już od okresu prenatalnego, poprzez statusowe symbole [Mikiewicz 2016: 164], wyznacza dziecku określone miejsce w strukturze społecznej i trwale wdrukowuje uczestnictwo w kulturze wysokiej w styl życia rodziny. Znane w literaturze modele osiągania statusu ukazują podstawowe znaczenie, jakie ma wyjściowa pozycja społeczna rodziny, z jakiej pochodzi dziecko (model Duncana-Blaua, za: Mikiewicz 2016: 121-122]. To „habitusy ukształtowane w danych warunkach realizują określony styl życia" [Gdula, Sadura, za: Mikiewicz 2016: 159], a zróżnicowanie społeczne będzie w tym rozumieniu zróżnicowaniem kapitału kulturowego.

Konsekwencją podjęcia tej gry przez przedstawicieli klasy wyższej jest zwiększanie szans ich dzieci na sprawne funkcjonowanie w ramach kultury prawomocnej - promowanej przez instytucję szkoły, a uznawanej za kanon. Kultura wysoka jest

rezerwuarem twórczości artystycznej i intelektualnej uznanych przez autorytety za dzieła wybitne, a ich odbiór wymaga specyficznych kompetencji. Szkoła to w gruncie rzeczy ćwiczenie w obcowaniu z kulturą wysoką albo w poruszaniu się w kulturze wysokiej, Kto posiądzie tę sztukę, ten będzie wysoko oceniony i zajdzie daleko (...). Kultura wysoka albo kultura prawomocna jest de facto kulturą klasy wyższej. Naturalnie zatem promuje przedstawicieli klasy wyższej, którzy uczą się jej kodów i symboli już w domu rodzinnym [Mikiewicz 2016: 165].

Oznacza to, że system edukacyjny jest „jedną z dróg zachowania dystynkcji kulturowej klasy dominującej. Klasa wyższa to ci, którzy potrafią się posługiwać symbolami kultury wysokiej” [Mikiewicz 2016: 166]. Umiejętność posługiwania się nimi staje się elementem selekcji szkolnej. Oznacza to, że stają się one jedynymi z czynników selekcyjnych współwystępujących wraz z pochodzeniem społecznym [Borowicz 2000].

Zapewne rodzice przez uczestnictwo w tych koncertach mogą - przynajmniej w pewnym zakresie - zaspokajać także własne potrzeby kulturalne i nie muszą martwić się o to, pod czyją opieką zostawić dziecko, ponieważ mogą przebywać w instytucji kultury i słuchać muzyki klasycznej na żywo wraz z nim. Koncerty obywają się zwykle o godzinie 12.30, czyli „przyjaznej” dla rodzin $\mathrm{z}$ niemowlętami i małymi dziećmi, cała instytucja jest przystosowana do tych koncertów - na schody do filharmonii wystawiane są podjazdy dla wózków, na podłodze rozwinięty jest dywan, by raczkujące dzieci 
mogły przebywać na czystej powierzchni, rodzice siedzą wraz z dziećmi na dywanie bez obuwia. Zawsze przygotowany jest przewijak, mamy podczas koncertu swobodnie karmią piersią. Można powiedzieć, że w tej patetycznej zwykle „świątyni muzyki”, stwarzane są dogodne warunki dla rodzin, co nie jest aż tak częstym zjawiskiem, więc warto te wysiłki podkreślić.

Koncepcja omawianych koncertów została opracowana na podstawie najnowszych doniesień psychologów muzyki, dotyczące pozytywnego wpływu muzyki klasycznej wykonywanej na żywo, przy użyciu bogatego instrumentarium na rozwój słuchu muzycznego, muzycznej wrażliwości oraz rozwój poznawczy płodu oraz najmłodszego dziecka, co można utożsamić z jej funkcją edukacyjną [por. Górniok-Naglik 2000, Bonna 2012, Sacher 2015: 209-214]. Z badań nad etapami rozwoju płodu wynika, że pęcherzyki słuchowe pojawiają się już cztery tygodnie po zapłodnieniu, po kolejnych sześciu tygodniach wytwarza się ślimak i narząd słuchu, a w 14-15 tygodniu funkcjonuje narząd Cordiego, mieszczący słuchowe receptory, „dlatego w piątym miesiącu płód może reagować przyspieszonym biciem serca i zwiększoną ruchliwością na bardzo silne dźwięki (...). W szóstym miesiącu życia płodowego mechanizm słyszenia działa podobnie jak u człowieka dorosłego", a nienarodzone dziecko zaczyna rozwijać pamięć muzyczną [Gluska 2012: 28, 30; por. Zwolińska 2016: 139], ucząc się powtarzalnego zachowania jako reakcji na określone sekwencje dźwięków. W ostatnich miesiącach ciąży „zauważalne jest także zjawisko habituacji słuchowej, wskazującej na umiejętność uczenia się przez płód zjawisk związanych z bodźcami dźwiękowymi” [Gluska 2012: 29]. Fakt ten potwierdzają eksperymenty ukazujące, że noworodek jest w stanie rozpoznać utwory muzyczne prezentowane mu podczas ciąży.

Badania te wskazują „na zdolność człowieka do rozwoju pamięci w okresie prenatalnym i wykorzystywania tych doświadczeń pamięciowych w okresie postnatalnym. Niektórzy badacze sądzą, że muzyczne wspomnienia z okresu prenatalnego mogą trwać nawet do roku" [Gluska 2007: 29]. Anna Nogaj (Gluska) psycholog muzyki twierdzi, że „stymulacja zmysłu słuchu w fazie prenatalnej poprzez mowę i muzykę daje dobre podwaliny dla rozwoju przyszłych zdolności językowych i muzycznych" [Gluska 2012: 29], a także może skutkować wyższym poziomem zdolności muzycznych. Ponadto muzyka dla płodu jest przyjemna, a badania pokazują, że dzieci stymulowane muzycznie wykazywały się „szybszym rozwojem funkcji językowych, większą aktywnością ruchową, lepszą koordynacją sensorycznoruchową (...) szybciej podejmowały wokalizację i gaworzenie w niemowlęctwie" [Gluska 2012: 31, por. Sacher 2015: 92]. 
Edukacja muzyczna dziecka w okresie płodowym jest zatem możliwa i badane koncerty są okazją do podjęcia tego procesu. Anna Nogaj w pracy „Rozwój zmysłu słuchu i muzycznej wrażliwości od okresu prenatalnego do wieku przedszkolnego" zaznacza, że naturalne zdolności płodu do uczenia się oraz "motywacja i zaangażowanie rodziców do wyjątkowej dbałości o prawidłowy i wszechstronny rozwój swojego dziecka" [Gluska 2012: 30] to dwa elementy zapewniające warunki edukacji muzycznej dziecka w okresie płodowym. Okres niemowlęcy to czas szczególnie intensywnego rozwoju dziecka oraz kształtowania się „wrażliwości sensoryczno-emocjonalnej na muzykę oraz początek aktywności muzycznej o charakterze reaktywnofunkcjonalnym" [Gluska 2012: 34], w tym czasie kształtują się typy reakcji na muzykę, koncentracja na muzyce, szczególnie, gdy jest ona wykonywana przez kogoś bliskiego dziecku (np. śpiew mamy) oraz świadomość muzyczna. Ponadto niemowlęta potrafią zapamiętywać muzykę oraz pierwsze wokalizacje. Psychologowie muzyki dowodzą, że niemowlęta intuicyjnie rozumieją sens przebiegu muzycznego [Thomson, za: Gluska 2012: 35] oraz są wrażliwe na rytm i rozpoznają nastrój utworu [Nawro, za: Gluska 2012: 36]. Stwierdzono ponadto, że niemowlęta rozpoznają melodie, rozróżniają metrum, zmiany barwy, długości nut. „W wieku dwóch miesięcy są w stanie odróżnić konsonans od dysonansu, przy czym preferują harmonijne brzmienia konsonansowe" [Zwolińska 2016: 139].

Kolejny etap, czyli wiek poniemowlęcy, stanowi czas „doskonalenia kategorii percepcyjnych”, rozwiniętych wcześniej, oraz rozwoju kompetencji wokalnych i ruchowych, a także wrażliwości artystycznej. Szczegółowe doniesienia z zakresu neurofizjologii oraz neuronauki, dotyczące rozwoju mózgu pod wpływem muzyki zostały opisane w pracach Doroty Karwowskiej i Agaty Kudlik Neurofizjologiczne mechanizmy odbioru i przetwarzania muzyki oraz pracach Ewy Zwolińskiej Społeczne znaczenie muzyki oraz Sens umuzykalniania. O celowości edukacji muzycznej.

Jak już wielokrotnie opisywano, wczesna edukacja muzyczna ma znaczący, pozytywny wpływ na rozwój ogólny, rozwój umysłowy, procesy poznawcze, strategie uczenia się i osiągnięcia w nauce. Dowiedziono, że dzieci pobierające naukę muzyki uzyskują lepsze wyniki w zadaniach czasowo-przestrzennych, aktywizują się motorycznie, ćwiczą umiejętności słuchowe, uczą się operowania symbolami, kształtują umiejętności werbalne korzystnie wpływające na naukę czytania. Ponadto liczne badania przywołane przez Natalię Wilsz dowiodły, że dzieci uczące się muzyki uzyskują lepsze wyniki w zadaniach pamięci werbalnej niż dzieci z grupy kontrolnej [Wilsz 2012: 146-147], a muzycy mają w lepszym stopniu rozwinięte 
umiejętności metapoznawcze (koncentrację, planowanie, monitorowanie własnych osiągnięć). Już w pierwszym roku życia kształtują się podstawy słuchu muzycznego, emocjonalnego reagowania na dźwięki grających zabawek, naśladowania gestów rytmicznych, rozpoznawania melodii, poruszania się przy muzyce [Lewandowska 2007: 14-15].

Edukacja muzyczna wydaje się mieć szczególnie dobroczynny wpływ na bardzo małe dzieci (...), gdyż w tym okresie następuje silny rozwój połączeń nerwowych i dodatkowe bodźce poznawcze mogą bezpośrednio wpływać na rozwój inteligencji ogólnej. Specjalne programy nauczania muzyki zaprojektowane dla najmłodszych umożliwiają rozbudzenie tych umiejętności w bardzo wczesnym wieku [Wilsz 2012: 148].

Ponadto, „zachowania związane z muzyką kształtują się od wczesnego dzieciństwa i rozwijają się w procesach społecznych, które są serią zmieniających się zjawisk, wywierających wpływ na osobowość jednostki” [Zwolińska 2016: 59, por. Sacher 2015: 214-218], a także pozwalają na doskonalenie rozumienia działań i emocji [Zwolińska 2016: 62-65]: dzieci lepiej kontrolują ekspresję emocjonalną, potrafią przywoływać uczucia oraz nastroje, mają bogatą wyobraźnię. Edukacja muzyczna wpływa także pozytywnie na rozwój społeczno-moralny: zespołowe przeżywanie, wykonywanie czy tworzenie muzyki daje szansę wchodzenia w interakcje społeczne, zajmowania prospołecznych postaw, umacniania więzi społecznych oraz wyzwalania postawy intrapersonalnej [Frołowicz 2015: 28-44], motywacji [Sacher 2015: 218-220].

Warto dodać, że liczne badania, szczególnie z zakresu psychologii muzyki dowiodły, że to środowisko rodzinne jest czynnikiem warunkującym muzykalność u dzieci [Lewandowska 2007: 23-33], a z drugiej strony muzyka może być formą wspierania socjalizacji [Jankowska 2004: 238-252].

Wszystkie te ustalenia wnoszą wiele do analiz tradycyjnych teorii wyjaśniających selekcje szkolne i edukacyjne szanse życiowe - na przykład teorii merytokratycznej „zasadzającej się na maksymalizacji założenia, że na coraz to wyższe szczeble kształcenia przechodzić powinna najlepsza, pozytywnie wyselekcjonowana część młodzieży" [Borowicz 2000: 27]. Przypomnijmy, że w społeczeństwie merytokratycznym o sukcesie (nagrodzie) w wymiarze ekonomicznym i psychologicznym decydować miały kompetencje. „Zaproponowana przez Y. Younga formuła 'zasługa = talent + wysiłek' zyskała powszechną aprobatę. Rozumowanie to oparte jest na założeniu, że u podstaw najwyższych kompetencji tkwi genotyp, wyposażenie biologiczne oraz 
kształcenie, włożona weń praca" [Borowicz 2000: 29]. Badania neuronaukowców oraz psychologów muzyki potwierdzają, że rozwój mózgu może być stymulowany na przykład przez słuchanie muzyki, zatem o poziomie inteligencji, zdolnościach nie decydują wyłącznie wrodzone predyspozycje, ale także wysiłek rodziców, którzy mając odpowiednią wiedzę, stymulują rozwój dziecka od wczesnych etapów życia prenatalnego starając się maksymalizować szanse potomka na życiowy, edukacyjny i zawodowy sukces [Dahrendorf 2006: 427-437].

Okazuje się zatem, że społeczne nierówności mogą mieć swoją genezę również w edukacyjnych oddziaływaniach rodziców na płód, na przykład przez uczestnictwo w zajęciach muzycznych, co wskazuje na przejaw skumulowanych przewag [Sztompka 2004: 358], jakie jedni mają nad drugimi już na etapie prenatalnym. Innymi słowy:

środowiska społeczne różnią się istotnie regułami kulturowymi, np. nawykami czytania, uczenia się, chodzenia do teatru, korzystania $\mathrm{z}$ wyższych form rozrywki (...). W rezultacie sukces końcowy w postaci zdobycia intratnego, prestiżowego czy dającego władzę zawodu jest w części tylko efektem własnych zasług, a w części warunków niezasłużonych, odziedziczonych zasobów materialnych czy kulturowych. Zdobywanie własnej pozycji społecznej jest więc zawsze w pewnej mierze powiązane z dziedziczeniem pozycji [Sztompka 2004: 363].

W tym miejscu należy przypomnieć znany w socjologii „teoremat Mateusza”, czyli pogląd, że „przywileje mają tendencję do powiększania, a upośledzenie - do pogłębiania się (...). Dystanse się powiększają, skala nierówności rozciąga coraz szerzej w obrębie każdej z hierarchii stratyfikacyjnych" [Sztompka 2004: 364-365].

Teoria ta wyjaśnia zjawiska zachodzące w społeczeństwie polskim. Badacze piszą wprost o narodowej głuchocie Polaków i swoistym analfabetyzmie w zakresie wiedzy muzycznej, niewrażliwości na muzykę klasyczną:

Polska jest krajem, w którym istnieje obecnie największy na świecie odstęp pomiędzy poziomem kompetencji i osiągnięciami muzycznej elity, zawodowych muzyków, twórców, wykonawców i słuchaczy koncertowych a przeciętnym poziomem kompetencji i zainteresowań muzycznych ogromnej większości społeczeństwa [Rakowski, za: Jabłońska 2014: 151].

Problem poziomu kształcenia muzycznego opisuje Barbara Jabłońska w Socjologii muzyki, ukazując systemowe braki w zakresie powszechnej edukacji muzycznej, będące jedną z przyczyn „międzygeneracyjnego 
dziedziczenia głuchoty”, czyli samoreprodukcji systemu [Jabłońska 2014: 153]. Oznacza to głębokie dystanse w społeczeństwie polskim w zakresie estetycznych dyspozycji, kompetencji artystycznych, rodzajach percepcji artystycznej oraz - co chyba najczęściej jest obserwowane - gustów muzycznych, które sprawiają, że ludzie żyją w zupełnie różnych społecznych światach, funkcjonując $\mathrm{w}$ ramach stylu życia reprezentowanej przez siebie klasy społecznej. Pierre Bourdieu uważał, że „zmysł dystynkcji” charakteryzuje klasę dominującą (wykazują najwyższe kompetencje kulturalne), „dobra wola kulturowa” - klasy średnie (które kultury nie znają, ale uznają), a „wybór konieczny” - klasy niższe (ludzie nieposiadający kulturalnych kompetencji), [Matuchniak-Kraususka 2010: 199-219]. Sam Bourdieu, cytując Kanta, pisał w Dystynkcji o ucieleśnionych strukturach społecznych oraz o tym, że:

gust jest dyspozycją nabytą w celu „rozróżniania” i „osądzania” (...) lub jak kto woli, ustalenia lub podkreślenia różnic poprzez ustalenie dystynkcji, która nie jest (czy też nie musi być) wyraźną wiedzą o znaczeniu, jakie nadaje temu słowu Leibnitz, skoro zapewnia rozpoznanie (w znaczeniu potocznym) przedmiotu, nie implikując wyraźnej znajomości cech dystynktywnych, jakie określają go w jego istocie [Bourdieu 2005: 572].

W drodze obserwacji uczestniczącej ustaliłam, że podczas koncertów przekazywana jest także wiedza muzyczna dotycząca podstaw teorii muzyki, ponadto dorośli wraz z dziećmi wyklaskują rytmy, śpiewają piosenki oraz melodie, które mogą potem śpiewać dzieciom lub wraz z nimi $\mathrm{w}$ domach. $\mathrm{Na}$ jednym $\mathrm{z}$ koncertów rodzice grali na instrumentach perkusyjnych po instruktażu artysty. Rodzice są dzieleni na głosy i śpiewają kanony - jest to również, poza edukacyjnym i emocjonalno-estetycznym oddziaływaniem na dzieci, element edukacji dorosłych. Ponadto, realizowane są zadania wpływające na podniesienie jakości komunikacji i pogłębienie bliskości między dzieckiem a rodzicem. Przykładowo, rodzice wraz z dziećmi bawią się w recytowanie wierszyków-masażyków, czyli prostych rymowanek połączonych ze znaczącym teatralnym ruchem i dotykiem („Równa droga”, „List do babci”, „Pizza”, „Pajączek” i wiele innych), wykorzystywanych często przez terapeutów oraz logopedów. Proponowane są wspólne tańce rodziców z dziećmi do muzyki klasycznej - na przykład walców, bolero. Do podobnych wniosków doszli Mayumi Adachi i Sandra Trehub, które badały koncerty „Od brzuszka do uszka maluszka”, a wnioski z obserwacji umieściły w pracy Musical Lives of Infants [Adachi, Trehub 2012: 243]. 
Trzeba podkreślić, że zdecydowana większość rodziców bierze bardzo aktywny udział we wszystkich zadaniach, zarówno ojcowie (unaoczniając nowy model ojca, częściej angażują się w opiekę nad dziećmi i mają na nie większy wpływ niż tradycyjni ojcowie [por. Szlendak 2010: 447]), jak i matki. Wytwarza się - jak udało się zaobserwować - swoista tożsamość grupy, która posiada symboliczne granice [Pawliszak 2007]. Podczas słuchania muzyki proponowane jest przytulanie dzieci, kołysanie, co można uznać za działanie odpowiadające koncepcji rodzicielstwa bliskości Searsów, czyli między innymi wpływanie na poczucie bezpieczeństwa i budowanie głębokiej więzi rodzicielskiej [Sears, Sears 2013]. Psychologowie muzyki dowodzą istnienia silnego związku między muzykoterapią a więzią emocjonalną, budowaniem przywiązania, pozytywnym jej wpływem na rozwój noworodków i wcześniaków oraz rodziców na etapie wchodzenia w nową rolę rodzicielską [Bieleninik 2015: 113-127].

$\mathrm{W}$ teorii interakcjonizmu symbolicznego uczestnictwo w koncercie jest działaniem znaczącym oraz symboliczną interakcją, która jest narzędziem konstrukcji społecznego świata wspólnoty intencjonalnej [Pawliszak 2007: 91] oraz nauką właściwego definiowania sytuacji [Hałas 2006: 139-222]. Koncert jest rytuałem interakcyjnym [Collins 2011, Pawliszak 2007: 89-90], konstruowanym spotkaniem, „w którym zgromadzona w jednym miejscu publiczność koncentruje swą uwagę na znaczącym obiekcie np. (...) artystycznym wydarzeniu" [Pawliszak 2007: 91]. Przejawy symbolizowanych emocji są gestami znaczącymi, czyli symbolami komunikującymi emocje współuczestnikom koncertu [Pawliszak 2007: 94].

Jeśli odczytanie jest zgodne z wewnętrznymi przeżyciami [widza - dop. A.N.K.] (...), to poprzez mechanizm opisywanej przez Blumera „kolistej” interakcji dokonuje się ich rozprzestrzenianie i wzmacnianie. Jako wzmocnione są wyrażane na zewnątrz, a z kolei odczytywane przez współuczestników widowiska wzmacniają natężenie i ujednolicają ich odczucia. W ten sposób emocje osiągają wyjątkowe i bardzo rzadko spotykane w codziennym życiu natężenie (...). W przebiegu rytuału emocjonalnie ładowane są także symbole grupowego uczestnictwa (...), powstaje poczucie solidarności, które łączone jest z daną wspólnotą wyobrażoną (...). Posiadanie wspólnych symboli wyrażających uczestnictwo w danej grupie umożliwia użycie ich we wzajemnych interakcjach i osiągnięcie wysokiego stopnia uwagi zogniskowanej na nich. Dostarczają one wspólnej treści do rozmów lub też zgodnych celów dla wspólnych działań (...). Struktura symboliczna społeczeństwa ułatwia kształtowanie się kreatywności jednostek, dając im poczucie przynależności i podmiotowości [Pawliszak 2007: 94-95]. 
Warto także zaznaczyć, że bliskość nie dotyczy wyłącznie rodziców i dzieci, ale można powiedzieć, że sztuka podczas omawianych koncertów jest „na wyciągnięcie ręki”, wręcz „na dotyk”. Zgodnie z ustaleniami psychologów muzyki, „dzieci przejawiają wielką potrzebę aktywności muzycznej i właściwie zorganizowany proces wychowawczy powinien umiejętnie wykorzystywać te tendencję" [Lewandowska 2007: I]. Dlatego, o ile to możliwe, muzycy w czasie koncertów, na przykład skrzypkowie, trębacze, klarneciści, bardzo często grają przechadzając się wśród publiczności. Dzieci mogą dotykać instrumentów, rodzice robią dzieciom zdjęcia z muzykami i instrumentami, czasem nawet sami grają, na przykład na instrumentach perkusyjnych, ale nie tylko (często dzieci przed lub po koncercie uderzają w klawisze filharmonicznego fortepianu lub chowają się pod nim uciekając rodzicom).

Niwelowane są tym samym tradycyjne dystanse między sceną a widownią, czyli ukryty program architektury budynków instytucji kultury, gdzie zawsze istnieje hierarchicznie wydzielona strefa dla występujących artystów oraz dla publiczności, która siedząc na swoim miejscu, w ciszy i skupieniu słucha koncertów, a jedyną jej aktywnością są oklaski. Badane koncerty ze względu na wiek słuchaczy charakteryzują się tym, że o skupieniu czy ciszy mowy być nie może, jednak dzieci rzadko płaczą, a nawet kilkumiesięczne, z otwartymi szeroko oczami i buziami, słuchają muzyki. Niektóre zasypiają w ramionach rodziców, inne uciekają im i kręcą się wśród wykonawców. Warto podkreślić, że publiczność jest włączana w aktywne uczestnictwo, a nie wyłącznie bierny odbiór. Z badań nad zachowaniem niemowląt wynika, że, jak pisze Barbara Kamińska, język muzyki jest dla nich szczególnie intrygujący, ponieważ:

muzyka charakteryzuje się tym, że ma szerszą niż mowa skalę dynamiczną, szerszy zakres wysokości dźwięku, bogatszą rytmikę, bogatszy świat barw dźwiękowych, bardziej uporządkowaną strukturę (powtarzalność). Świat dźwięków może być zatem dla niemowlęcia znaczącym obszarem, nowych doznań, które rozszerzą jego możliwości poznawcze. Nade wszystko jednak - ma zdolność wywoływania różnorodnych nastrojów i emocji. Te emocjonalne aspekty kontaktów z muzyką są nierozłącznie związane z kształtowaniem preferencji, postaw i motywacji muzycznych [Kamińska 2010: 7]. 


\section{Podsumowanie}

W wyniku realizacji procesu badawczego, przeprowadzenia obserwacji uczestniczącej, wywiadów swobodnych oraz analizy dokumentów zastanych udało się odpowiedzieć na postawione problemy badawcze. Wskazałam na społeczne funkcje uczestnictwa w badanych koncertach. Zaprezentowałam, jaka jest koncepcja oraz założenia programowe oraz metodyczne cyklu koncertów. W wyniku analizy zebranego materiału badawczego przedstawiłam schemat oraz przykłady przebiegu koncertów, a w artykule szczegółowo ukazałam zarówno teoretyczne, jak i wynikające z praktyki społecznej ustalenia poczynione $\mathrm{w}$ tym zakresie. $\mathrm{W}$ trakcie analizy ukazałam znaczenie słuchania muzyki przez dzieci w okresie prenatalnym i małe dzieci na ich rozwój poznawczy, emocjonalny. Wydaje się, że świadome rodzicielstwo, w tym udział w koncertach, takich jak te z cyklu „Od brzuszka do uszka maluszka”, może różnicować edukacyjne szanse życiowe, wyznacza status społeczny, kształtuje kapitał kulturowy oraz społeczny dzieci. Mam nadzieję, że niniejszy artykuł wpisuje się w nurt poszukiwań odpowiedzi na pytanie stawiane często przez socjologów edukacji: „od czego zależy nasz edukacyjny los?" [Mikiewicz 2014: 51], jak przebiega edukacja dla sukcesu oraz kreowanie biografii dziecka nastawionej na maksymalizację szans życiowych i edukacyjnych? W artykule wskazałam na nieczęsto ukazywane czynniki i mechanizmy warunkujące selekcje szkolne, działania społeczne warunkujące trajektorie sukcesu życiowego, a także procesy składające się na osiąganie statusu społecznego, budowanie społecznej tożsamości, reprodukowanie struktury społecznej przez rodzinę i przez unikatowe sposoby uczestnictwa w kulturze wysokiej.

\section{Bibliografia}

Adachi M., Trehub S. (2012), Musical Lives of Infants, [w:] G. McPherson, G. Welch, The Oxford Handbook of Music Education, t. 1, Oxford.

Adorno T. W. (1990), Sztuka i sztuki. Wybór esejów, Warszawa.

Angrosino M. (2010), Badania etnograficzne i obserwacyjne, Warszawa.

Babbie E. (2005), Badania społeczne w praktyce, Warszawa.

Białkowski A. (2006), Edukacja muzyczna jako dyskurs, [w:] W. A. Sacher, Sacrum - sztuka - wychowanie, Kraków.

Bieleninik Ł. (2015), Muzykoterapia a więź emocjonalna, [w:] J. Kaleńska-Rodzaj, R. Lewandowski (red.), Psychologia muzyki. Pomiędzy wykonawca a odbiorca, Gdańsk. 
Blumer H. (2007), Interakcjonizm symboliczny, Kraków.

Bonna B. (2012), Muzyka w okresie prenatalnym. Zaangażowanie kobiet w ciąży we wspieranie rozwoju muzycznego dziecka, [w:] eadem, Historyczne i współczesne aspekty badań nad kultura muzyczną i poezja, Bydgoszcz.

Borowicz R. (2000), Nierówności społeczne w dostępie do wykształcenia. Casus Suwalszczy$z n y$, Olecko.

Bourdieu P. (1990), Reprodukcja. Elementy teorii systemu nauczania, Warszawa.

Bourdieu P. (2005), Dystynkcja. Społeczna krytyka władzy sądzenia, Warszawa.

Bourdieu P. (2006), Struktury, habitus, praktyki, [w:] P. Sztompka, M. Kucia (red.), Socjologia. Lektury, Kraków.

Budd M. (2014), Muzyka i emocje, Gdańsk.

Collins R. (2011), Łańcuchy rytuałów interakcyjnych, Kraków.

Czarniawska E. (2012), Muzyka i my. O różnych przejawach wpływu muzyki na człowieka, Warszawa.

Dahrendorf R. (2006), O pojęciu szans życiowych, [w:] P. Sztompka, M. Kucia (red.), Socjologia. Lektury, Kraków.

Domański H. (2004), Struktura społeczna, Warszawa.

Drozdowski R. i in. (2014), Praktyki kulturalne Polaków, Toruń.

Elliott A. (2011), Współczesna teoria społeczna, Warszawa.

Fatyga B. (2014), Wartości jako generatory żywej kultury, [w:] R. Drozdowski i in., Praktyki kulturalne Polaków, Toruń.

Filipiak M. (2003), Socjologia kultury. Zarys zagadnień, Lublin.

Frołowicz E. (2015), Jestem Inny!: Muzyczna edukacja wczesnoszkolna a problematyka wielokulturowości, „Aspekty Muzyki”, nr 5, http://bazhum.muzhp.pl/media//files/ Aspekty_Muzyki/Aspekty_Muzyki-r2015-t5/Aspekty_Muzyki-r2015-t5-s79-93/ Aspekty_Muzyki-r2015-t5-s79-93.pdf, [01.03.2018].

Frołowicz E. (2015), Rozwój ogólny a rozwój muzyczny dziecka. O pożytkach z kształcenia muzycznego płynących, [w:] A. Delecka-Bury, Współczesne wyzwania szkolnictwa muzycznego, Toruń.

Gluska A. (2012), Rozwój zmysłu słuchu i muzycznej wrażliwości od okresu prenatalnego do wieku przedszkolnego, [w:] E. Czarniawska, Muzyka i my. O różnych przejawach wpływu muzyki na człowieka, Warszawa.

Goffman E. (2006), Rytuat interakcyjny, Warszawa.

Goffman E. (2008), Zachowanie w miejscach publicznych, Warszawa.

Goffman E. (2010), Analiza ramowa, Kraków.

Golka M. (2007), Socjologia kultury, Warszawa.

Górniok-Naglik A. (2000), Muzyka a rozwój małego dziecka, [w:] B. Dymara, Dziecko w świecie muzyki, Kraków.

Gromkowska-Melosik A., Gmerek T. (2008), Problemy nierówności społecznej w teorii i praktyce edukacyjnej, Kraków.

GUS (2016), Uczestnictwo ludności w kulturze w 2014 roku, Warszawa.

Hałas E. (2006), Interakcjonizm symboliczny, Warszawa. 
Kamińska B. i in. (2010), Płyta wraz z opisem założeń programowych koncertów „Od brzuszka do uszka maluszka", Bydgoszcz.

Jabłońska B. (2014), Socjologia muzyki, Warszawa.

Jankowska K. (2004), Muzyka jako forma wspierania socjalizacji u dzieci w wieku szkolnym, [w:] M. Knapik, W.A. Sacher, Sztuka w edukacji i terapii, Kraków.

Kaleńska-Rodzaj, Lewandowski R. (2015), Psychologia muzyki. Pomiędzy wykonawca a odbiorca, Gdańsk.

Kisiel M. (2007), Pedagogiczne-dydaktyczne aspekty wykorzystania muzyki $w$ stymulacji rozwoju dziecka, Dąbrowa Górnicza.

Kolankiewicz L. (2010), Antropologia widowisk. Zagadnienia i wybór tekstów, Warszawa.

Krzemińska E. (2012), Edukacja muzyczna nie tylko w szkole, [w:] A. Białkowski, Nowe obszary i drogi rozwoju edukacji muzycznej w Polsce, Warszawa.

Lewandowska K. (2007), Muzykoterapia dziecięca, Gdańsk.

Linton R. (1975), Kulturowe podstawy osobowości, Warszawa.

Maślanka T., Strzyczkowski K. (2012), Między rutyna a refleksyjnością. Praktyki kulturowe i strategie życia codziennego, Warszawa.

Matuchniak-Krasuska (2010), Zarys socjologii sztuki Pierre 'a Bourdieu, Warszawa.

Mayntz R., Holm K., Hübner P. (1985), Wprowadzenie do metod socjologii empirycznej, Warszawa.

Meighan R. (1993), Socjologia edukacji, Toruń.

Mencwel A. (2005), Antropologia kultury. Zagadnienia i wybór tekstów, Warszawa.

Mikiewicz P. (2014), Kapitał społeczny i edukacja, Warszawa.

Mikiewicz P. (2016), Socjologia edukacji, Warszawa.

Mrozowicz-Wrońska M., Cipora K., Czernecka K. (2015), Psychologiczne determinanty afektywnego aspektu przekazu muzycznego, [w:] Kaleńska-Rodzaj, R. Lewandowski, Psychologia muzyki. Pomiędzy wykonawca a odbiorca, Gdańsk.

Pawliszak P. (2007), Symboliczne i rytualne aspekty czasu wolnego, [w:] K. Ciżkowicz, M. Sobczak, Czas wolny - uwarunkowania społeczno-ekonomiczne i przyrodnicze, Bydgoszcz.

Pikała A. (2002), Dokształcanie i doskonalenie zawodowe nauczycieli muzyki i plastyki $w$ świetle aktualnych potrzeb edukacyjnych i uwarunkowań społeczno-kulturalnych, [w:] V. Przeremska, Problemy współczesnej edukacji muzycznej, Łódź.

Pikała A. (2015), Rola kreatywnych cech i kompetencji nauczycieli szkół muzycznych I stopnia w rozwijaniu postaw twórczych uczniów, [w:] A. Delecka-Bury, Współczesne wyzwania szkolnictwa muzycznego, Toruń.

Sacher W. A. (2004), Stuchanie muzyki klasycznej a kształtowanie emocjonalności dzieci, [w:] M. Knapik, W. A. Sacher, Sztuka w edukacji i terapii, Kraków.

Sacher W. A. (2006), Rozumienie pojęć aksjologicznych przez dzieci w sytuacji koncertowej edukacji muzycznej, [w:] idem Sacrum - sztuka - wychowanie, Kraków.

Sacher W. A. (2015), Pedagogika muzyki. Teoretyczne podstawy powszechnego kształcenia muzycznego, Kraków.

Schutz A. (2008), Wspólne tworzenie muzyki. Studium relacji społecznych, [w:] idem, O wielości światów, Kraków 
Sears W., Sears M. (2013), Księga Rodzicielstwa Bliskości, Warszawa.

Suświłło M. (2006), Psychospołeczny wymiar edukacji muzycznej - między transmisja kulturowa a modelem interakcyjnym, [w:] Sacher W. A., Sacrum - sztuka - wychowanie, Kraków.

Szacki J. (2002), Historia myśli socjologicznej, Warszawa.

Szlendak T. (2010), Socjologia rodziny, Warszawa.

Szlendak T. (2014), Formy aktywności kulturalnej, [w:] R. Drozdowski i in., Praktyki kulturalne Polaków, Toruń.

Sztompka P. (2004), Socjologia. Analiza społeczeństwa, Kraków.

Turner J. H., Stets J. E. (2009), Socjologia emocji, Warszawa.

Turner J.H. (2012), Struktura teorii socjologicznej, Warszawa.

Zalewska-Pawlak M. (2001), Rola sztuki w wychowaniu. Polska tradycja pedagogiczna, Łódź.

Zwolińska E. (2016), Sens umuzykalniania. O celowości edukacji muzycznej, Bydgoszcz.

Zwolińska E. (2015), Społeczne znaczenie muzyki, Bydgoszcz.

\section{SUMMARY}

\section{Social Functions and Educational Significance of the Participation of Pregnant Women and Small Children in Classical Music Concerts}

The article is devoted to the presentation of the results of a research on the social functions and importance of participation in classical music concerts for pregnant women, infants, and young children, organized by the Pomeranian Philharmonic in Bydgoszcz. The research project was devoted to exploring such functions of music, as education and entertainment, as well as the functions of family in reference to stratification, socialization, identification, and emotions, as it is the family that, through participation in the high-brow culture from the prenatal period, for one thing, determines a child's place in the social structure, and permanently imprints participation in this king of culture as a lifestyle. In Sociology of Music, Barbara Jabłońska writes that music also fulfils a distinctive and segregational function, that is, promotes class divisions in a society, as it diversifies social positions by means of consumption of certain musical genres. It seems that the concerts discussed in the article may have such a function in relation to the ways of spending free time by families. Participation in concerts for pregnant women, infants, and young children is a means of reproduction of social position by families who are aware of the scientifically proven positive impact of participation in high-brow culture on the child's cognitive and emotional development. Conscious parenting, including participation in this type of concerts, can support the educational life chances of children. The article is based on a participant observation and interviews with the promoters of the concerts, as well as an analysis of the literature on the subject.

KEYWORDS: class distinction, classical music concerts for pregnant women and small children, cultural capital, educational life chances, music education, social inequality 